\title{
Stability Evaluation of Orthodontic Treatment of a Severe Open Bite Problem for an Adult by Maxillary Molar Intrusion Using Zygomatic Mini-Plates and Premolar Extractions: A 5 Year Follow Up Results
}

\section{Zygoma Mini Plak Kullanılarak Maksiller Molar İntrüzyonu ve Küçük Azı Çekimi Yoluyla Şiddetli Açık Kapanışın Ortodontik Tedavisinin Stabilite Değerlendirmesi: 5 Yıllık Takip Sonuçları}

\author{
Necati Türkmen $^{1}$ (i), Gülnaz Marșan ${ }^{1}$ (D)
}

1 Istanbul University, Faculty of Dentistry, Department of Orthodontics, Istanbul, Turkey

ORCID: N.T. 0000-0002-8346-1042; G.M. 0000-0003-3278-3372

Corresponding author/Sorumlu yazar: Necati Türkmen,

Istanbul University, Faculty of Dentistry, Department of Orthodontics, Istanbul, Turkey E-mail: najatee.kamal@gmail.com

Submitted/Geliș tarihi: 27.11.2020 First Revision Received/İlk revizyon: 24.12 .2020 Last Revision Received/Son Revizyon: 25.12.2020 Accepted/Kabul Tarihi: 20.01.2021

Citation/Atıf: Turkmen N, Marsan G. Stability evaluation of orthodontic treatment of a severe open bite problem for an adult by maxillary molar intrusion using zygomatic mini-plates and premolar extractions. Sağlık Bilimlerinde İleri Arastırmalar Dergisi 2021; 4(1): 49-53. https://doi.org/10.26650/JARHS2021-842364

\begin{abstract}
Relapse of the open bite following the orthodontic treatment may occur within various periods after finishing active treatment. This study evaluates the stability of a severe open bite treatment using records taken 5 years after the treatment. Clinical Presentation: A 16- year old female patient with severe anterior open bite of $(-6 \mathrm{~mm})$ and skeletal $\mathrm{Cl}$ II relation owing to mandibular retrognathia and dental $\mathrm{Cl}$ I occlusion and moderate crowding in both arches. The patient was treated with maxillary molar intrusion with the help of zygomatic miniplates and NiTi coil springs tied to maxillary bite blocks to reduce the lower face height and to close the negative overbite and premolar extractions were also performed to relieve the crowding followed by conventional fixed orthodontic treatment. Conclusion: the patient showed stable vertical correction and a relapse only in the form of diastema at the extraction site. This type of treatment is recommended for similar cases since it has good stability in the long term, and it is less invasive than the orthognathic surgery with less postoperative complications expected. Keywords: Orthodontics, intrusion, zygoma, stability, open bite
\end{abstract}

Öz

Ortodontik tedaviyi takiben açık kapanışta görülen nüks, aktif tedavi bittikten sonra çeşitli dönemlerde ortaya çıkabilir. Bu çalışma, tedaviden 5 yıl sonra alınan kayıtları kullanarak şiddetli bir açık kapanış tedavisinin stabilitesini değerlendirmektedir. Klinik Bulgular: Mandibuler retrognati ve dental $\mathrm{Cl}$ I oklüzyonuna sahip şiddetli ön açık kapanış (-6 mm), iskeletsel $\mathrm{Cl}$ II iliş̧i ve her iki arkta orta derecede çapraşılılık gosteren 16 yaşında kadın hastaya ait. Alt yüz yüksekliğini ve açık kapanışı azaltmak için Zigomatik miniplaklara bağlanan NiTi yaylar yardımıyla üst çene molar intrüzyonu yapıldı. çapraşıklı̆ı gidermek için premolar çekimleri ve geleneksel sabit ortodontik tedavi uygulandı. Sonuç: dik yöndeki ortodontik düzelmenin stabil olduğu görüldü .Çekim yerinde minimal aralık şeklinde bir nüks bulundu. Bu tür bir tedavi, uzun vadede iyi stabilite gostermektedir ve ortognatik cerrahiye göre daha az invaziv olduğu ve postoperatif komplikasyon yaratmadiği için benzer vakalar için önerilebilir. Anahtar Kelimeler: Ortodonti, intruzyon, zygoma, stabilite, açık kapanış 


\section{INTRODUCTION}

Open bite cases in adults is one of the most difficult and the most susceptible cases to relapse after orthodontic treatment $(1,6)$. Tooth extractions may become necessary in open bite corrections and the treatment stability of both extraction and non-extraction treatment has been studied extensively $(7,8)$. Increased lower facial height due to elongated maxillary posterior segment necessitates the help of surgical interventions since it cannot be reduced by fixed orthodontic treatment alone which can lead to unfavourable elongation of upper incisors and a gummy smile $(4,9)$. Surgical interventions such as single or double jaw surgery for posterior maxillary impaction and jaw repositioning is often needed $(6,10)$. Recently a less invasive method has been shown to be effective by intruding the maxillary molars with the anchorage derived from zygomatic mini plates tied to posterior bite blocks covering the upper molars and premolars $(1,3,6,10,11)$. The long term stability following this method of treatment has been studied in a number of studies 1 and 4 years posttreatment $(3,6)$. This case report evaluates the treatment outcomes and stability 5 years posttreatment.

\section{CLINICAL PRESENTATION Diagnosis}

A 16-year-old female patient seeking treatment with a chief complaint of anterior open bite. In the extra oral examination, the patient showed increased lower face height and retrognathic mandible together with incompetent lips. Intraorally the patient had moderate crowding in both the upper arch and the lower arch. The main discrepancies were in the vertical relations with a negative overbite of $6 \mathrm{~mm}$ anteriorly and a lateral open bite extending to the first premolars (Figure 1).

\section{Treatment Progress}

First the infra zygomatic plates were surgically placed followed by the bonding of the maxillary appliance and application of the intrusive force (Figure 2). The total intrusion time was 9 months with periodic activations of the NiTi coils. After

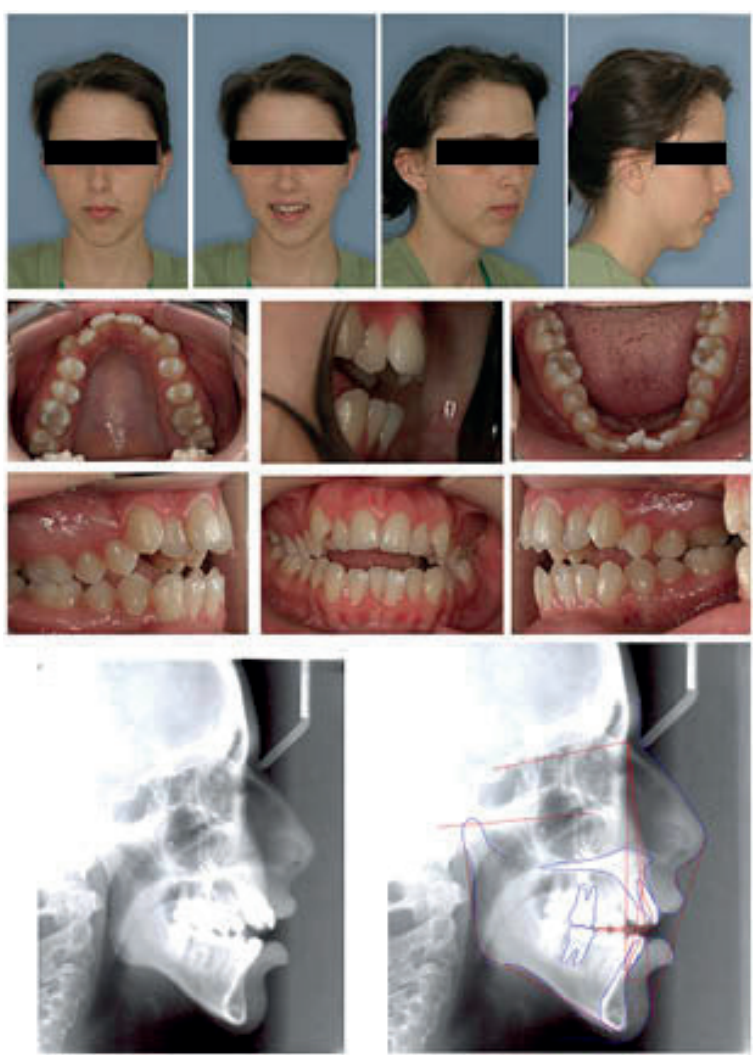

Figure 1. Extra and Intra oral records before treatment.
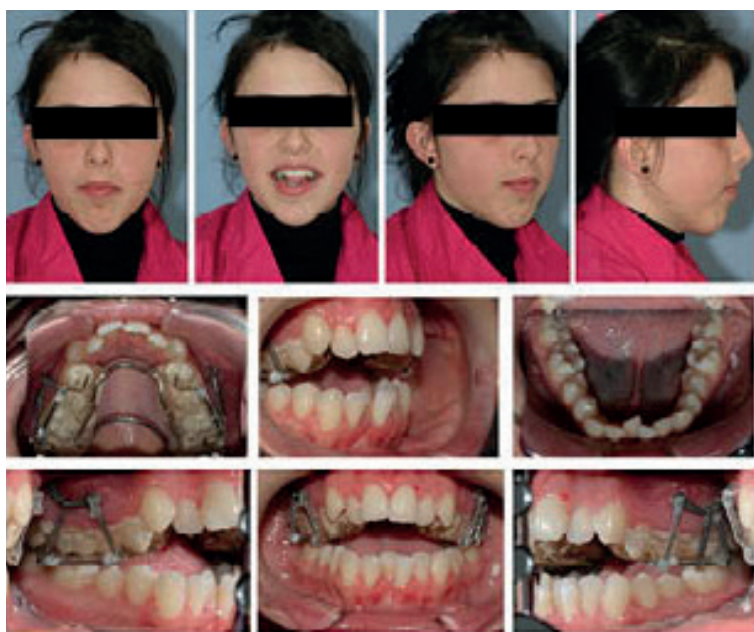

Figure 2. Extra and Intra oral photos at the day of bonding of the appliance.

removing the bite block, the open bite was reduced to an edge to edge relation as seen in the photographs and cephalometric radiograph and cephalometric and then premolar extractions were performed followed by fixed orthodontic treatment with bonded brackets (0.018-inch, Roth edgewise appliances) (Figure 3). Intrusion followed by ex- 


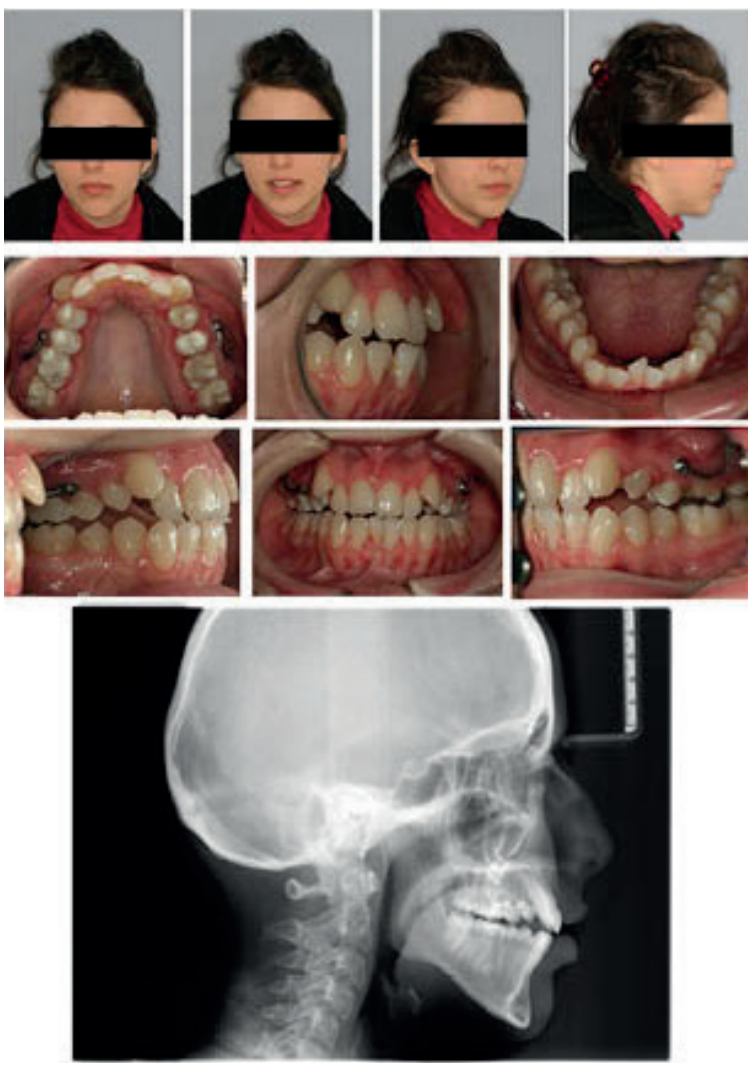

Figure 3. Extraoral and intraoral records after completion of intrusion and debonding of the appliance.

tractions were carried out in this patient to resolve the crowding and to allow correction of the class II relationship. The total treatment time is 3 years and 9 months. F ixed bonded retainers from canine to canine were applied to both arches. The patient then deferred the removal of the zygomatic implants.

\section{RESULTS}

The ideal overbite and overjet was achieved and the anterior open bite was eliminated and the facial and dental aesthetics showed pleasing improvements (Figure 4).

\section{5 year follow up results}

The correction of the overbite and overjet was stable, and the patient showed no complaints. The occlusion was stable with mild reopening of the extraction site between the lower left canine and premolar and a broken fixed lingual retainer (Figure 5).

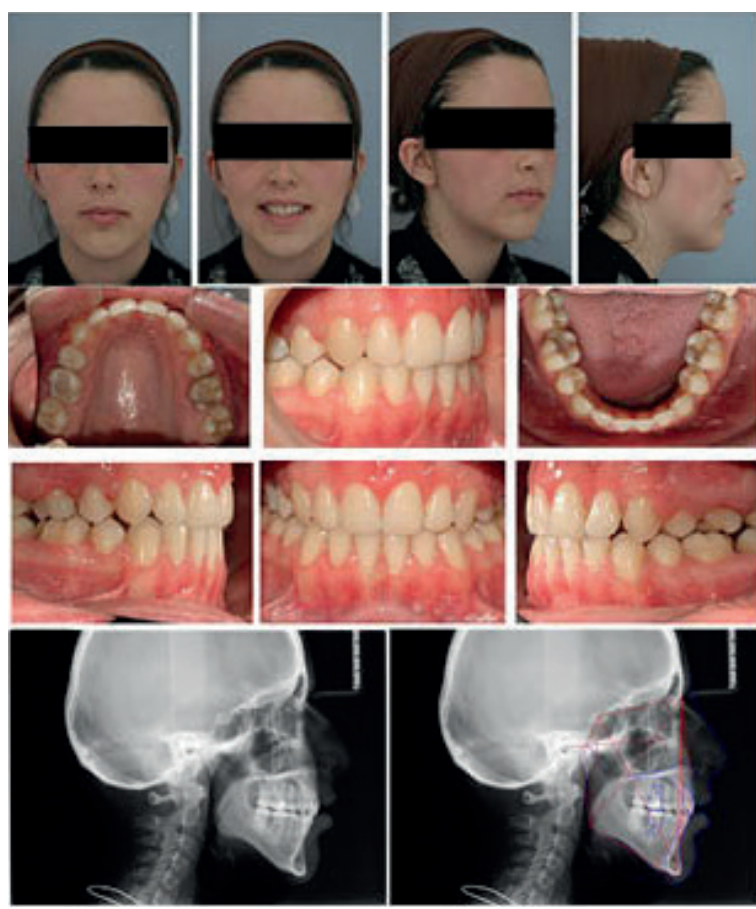

Figure 4. Extraoral and Intraoral records at the finishing of the fixed orthodontic treatment.

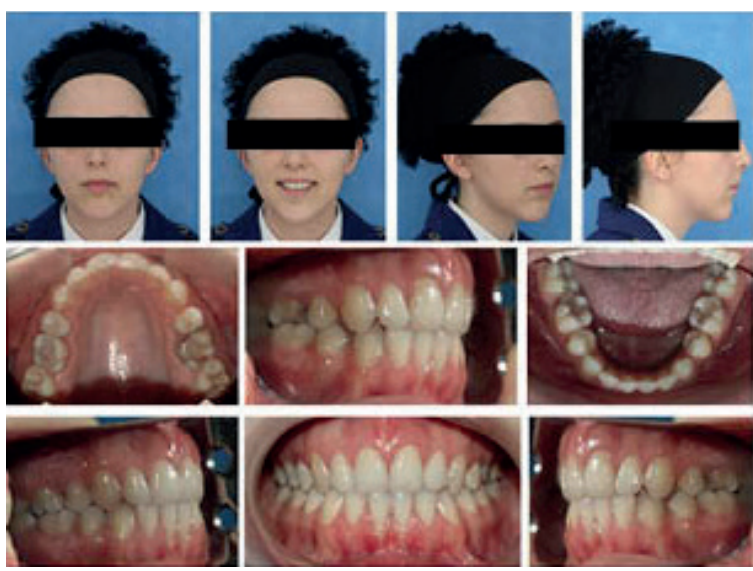

Figure 5. Extraoral and Intraoral records after five years of finishing the orthodontic treatment.

\section{DISCUSSION}

Open bite treatment protocols show great versatility because of its variable clinical presentations owing to its multifactorial aetiology.

Decision on the treatment choice depends on a number of factors including the patient's medical history, severity of the open bite and dental and gingival show. Treatments that include extrusion of incisors should be avoided in patients with good incisors, which 
would leave limited choices to decide from in order to correct the overbite. Using infrazygomatic miniplates or orthodontic mini-screws to intrude the upper posterior teeth have been introduced as an alternative to surgical correction $(4,11)$. During intrusion an appliance in the form of an acrylic bite block is bonded on the maxillary molars and premolars connected by two transpalatal bars. This approach gives three benefits: first, it prevents buccal flaring of the intruded teeth, secondly, by its bite raising part, it aids in the intrusions by stretching the masticatory muscles and lastly, the transpalatal bars are bent to be around $4 \mathrm{~mm}$ away from the palatal mucosa to aid in the intrusion by the muscular activity of the tongue pressing against the palatal bars. The amount of intrusion and its effects on the facial heights can be seen in the radiographic superimpositions of the intrusion phase and in the superimposition of the whole treatment and in the photographic follow up photos (Figure 6, 7). During the following fixed orthodontic treatment, care should be taken to

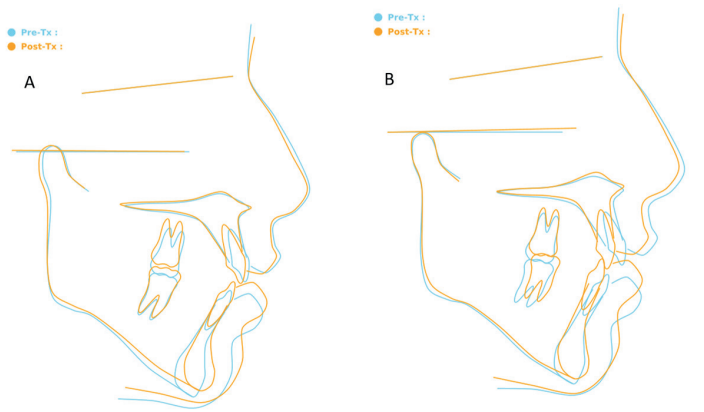

Figure 6. Radiographic superimpositions for radiographs taken A)before bonding and after removal of acrylic splint. B)before treatment and after debonding of the fixed brackets.
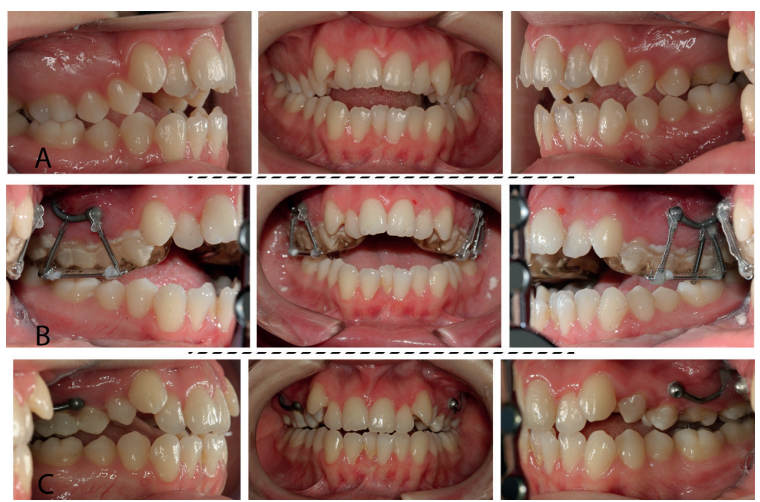

Figure 7. Follow up photographs taken A)before bonding B) during intrusion $\mathrm{C}$ ) after removal of acrylic splint showing the amount of intrusion. avoid re-extrusion of the posterior teeth by keeping the arch wire tied passively to the miniplate arm. The follow up results after 5 years showed stable outcomes regarding the vertical correction with minor reopening of the extraction site due to retainer compliance.

\section{CONCLUSION}

After careful patient selection, the zygomatic mini plate assisted intrusion of the posterior teeth is an effective treatment option to reduce the posterior vertical maxillary excess in moderate anterior open bite patients with stable outcomes in the long term.

Peer Review: Externally peer-reviewed.

Hakem Değerlendirmesi: Dış bağımsız.

Informed Consent: Written consent was obtained from the participants.

Bilgilendirilmiş Onam: Katılımcılardan bilgilendirilmiş onam alınmıștır.

Author Contributions: Conception/Design of Study- G.M., N.T.; Data Acquisition- N.T.; Data Analysis/Interpretation- G.M., N.T.; Drafting ManuscriptN.T.; Critical Revision of Manuscript- G.M.; Final Approval and Accountability- G.M., N.T.

Yazar Katkıları: Çalışma Konsepti/Tasarım- G.M., N.T.; Veri Toplama- N.T.; Veri Analizi/YorumlamaG.M., N.T.; Yazı Taslağı-N.T.; İçeriğin Eleștirel İncelemesi- G.M.; Son Onay ve Sorumluluk- G.M., N.T.

Conflict of Interest: Authors declared no conflict of interest.

Çıkar Çatışması: Yazarlar çıkar çatışması beyan etmemişlerdir

Financial Disclosure: Authors declared no financial support.

Finansal Destek: Yazarlar finansal destek beyan etmemişlerdir.

Acknowledgement: We thanks to for his contributions, Dr. Mahmut Diker.

Teşekkür: Katkılarından dolayı Dr. Mahmut Diker’e teşekkür ederiz.

\section{REFERENCES}

1. Erverdi N, Acar A. Zygomatic anchorage for en masse retraction in the treatment of 
severe Class II division 1. Angle Orthod 2005;75(3):483-90.

2. Espeland L, Dowling PA, Mobarak KA, Stenvik A. Three-year stability of open-bite correction by 1-piece maxillary osteotomy. Am J Orthod Dentofacial Orthop 2008;134(1):60-6.

3. Baek MS, Choi YJ, Yu HS, Lee KJ, Kwak J, Park YC. Long-term stability of anterior open-bite treatment by intrusion of maxillary posterior teeth. Am J Orthod Dentofacial Ortho 2010;138(4):396 e1-9.

4. Deguchi T, Kurosaka H, Oikawa H, Kuroda S, Takahashi I, Yamashiro T, et al. Comparison of orthodontic treatment outcomes in adults with skeletal open bite between conventional edgewise treatment and implant-anchored orthodontics. Am J Orthod Dentofacial Orthop 2011;139(4 Suppl):S60-8.

5. Fontes AM, Joondeph DR, Bloomquist DS, Greenlee GM, Wallen TR, Huang GJ. Longterm stability of anterior open-bite closure with bilateral sagittal split osteotomy. Am J Orthod Dentofacial Orthop 2012;142(6):792-800.

6. Marzouk ES, Kassem HE. Evaluation of longterm stability of skeletal anterior open bite correction in adults treated with maxillary posterior segment intrusion using zygomatic miniplates. Am J Orthod Dentofacial Orthop 2016;150(1):78-88.

7. Janson G, Valarelli FP, Henriques JF, de Freitas MR, Cancado RH. Stability of anterior open bite nonextraction treatment in the permanent dentition. Am J Orthod Dentofacial Orthop 2003;124(3):265-76;quiz 340.

8. de Freitas MR, Beltrao RT, Janson G, Henriques JF, Cancado RH. Long-term stability of anterior open bite extraction treatment in the permanent dentition. Am J Orthod Dentofacial Orthop 2004;125(1):78-87.

9. Sassouni V. A classification of skeletal facial types. Am J Orthod 1969;55(2):109-23.

10. Beycan K, Erverdi N. Anterior open-bite treatment by means of zygomatic miniplates: a case report. J Istanb Univ Fac Dent 2017;51(1):52-6.

11. Erverdi N, Keles A, Nanda R. The use of skeletal anchorage in open bite treatment: a cephalometric evaluation. Angle Orthod 2004;74(3):381-90. 